\title{
English Language Teaching in Rural Areas: A Scenario and Problems and Prospects in Context of Bangladesh
}

\author{
Md.Mahroof Hossain \\ Department of English, Z.H Sikder University of Science \& Technology, Bangladesh \\ E-mail: mahroof.hossainsarker@gmail.com
}

Doi:10.7575/aiac.alls.v.7n.3p.1

URL: http://dx.doi.org/10.7575/aiac.alls.v.7n.3p.1
Received: 02/01/2016

Accepted: 15/02/2016

\begin{abstract}
Language is one of the medium of expressing our ideas, feelings and emotions. And if we think about language in present world then English is one of the most used languages in the world and English is used as a second language in Bangladesh. English is introduced here at the primary level and its inclusion continues till the tertiary level of education. Most of the students of the primary schools in rural areas are weak in English language due to lack of skilled and trained teachers who are familiar to the modern methods and approaches of teaching and lack of materials for teaching in the classroom. Primary level English curriculum implementation is essential in Bangladesh to achieve the set English language competency in the rural areas. Students in the rural areas are performing poorly in English compared to their urban counterparts. Statistics showed that there was a gulf of difference between the facilities enjoyed by rural schools and urban schools. The study explores the challenges of teaching English language in rural areas in context of Bangladesh. This study investigated the factors affecting student's performance in English language in rural areas. Data were collected using interviews, classroom observation and questionnaire. Result of the study reveals that students were highly motivated to learn English for future expectations such as local and international communication, academic advancement and employment prospects. It also provide a scenario of English teaching system in rural areas of Bangladesh as well as the problems and prospects of English language in perspective of Bangladesh.
\end{abstract}

Keywords: English language, rural areas, education, learning and teaching, competency

\section{Introduction}

Language is one of the most useful tools we have as humans. Without it we could not think of thoughts expressible to others, nor could we engage in the activities that commonly take place in the society we build ourselves (Di Pietro, 1994). Language is very important in education. The high status of English within a global economy of languages has meant that English language education is increasingly being promoted in international development initiatives. A broad goal of English language programs is that of developing the communicative ability to convey and interpret a message via written or spoken modalities to another person. In our country, there is no doubt that we still have not established a standard of education in schools and colleges. There are too many problems in our country that have to be eradicated to embrace a comprehensive education system through which we can expect ourselves to be a richer nation. We must not forget that students today will become the key members of our country who would be responsible for the overall development of our country. If we do not have good teacher, there is no way we could expect to have a balanced society in future. And if there are not enough good teachers in English, then there would be imbalance that the urban area students will be good at English, but students in rural areas would always be deprived of getting or learning English properly. The main objectives of teaching English in Bangladesh are to enable students to understand simple commands, instructions and requests in English and also carry them out. (National curriculum and Textbook Boards 2006). Most of the students of rural schools are unable to attain the primary English language competencies due to prevailing challenges in our education system. The main objective of this research is to find out the challenges and problems and prospects of English language teaching in rural areas in context of Bangladesh.

\section{Factors that making a difference in performance of English language in rural and urban area}

In the present world, education is the most important aspect in society development. For education school is considered to play a major role in ensuring the successful of the development. It is not only the institution but also the students have to play to be proactive with an appropriate futuristic set of mind. The students also need to have good skills as well as they also need to be active in co-curriculum activity along with high academic achievement. Apart from all this factors the environment where the student's lives can determine their performance in their studies. In short, we can say that reason for the variations in their performance in learning and achievement are geographical location, resources, availability of technology and also the quality of teachers.

Urban area relates to the area that are surrounding by cities and it is well populated areas compared to rural area which is sparsely populated areas and it usually farmland or country areas. Recent educational research has examined rural and 
urban differences in their achievement. Many educators, researchers, legislators and the general public believe that students from rural schools mostly receive an education that is inferior compared to the students that live in the urban areas. And if it is about the question teaching or the matter about the acquisition of second language that is English the situation is worst.

There are many factors that contribute to the differences of performance in English language between students in rural and urban areas.

\subsection{Family factors}

To determine the child performance their family plays a key role. Students in rural areas have low performance compared to students in urban areas because it is relate to their parents education.Some experts believe that parents expectations is the most influencial factor affecting youth decisions to pursue education. (Esterman and Hedland,1995; smith,Beaulieu and Seraphine,1995).

\subsection{Financial factor}

The students' background relates to low socio-economic factor of their family also one of the factor that affect their performance in English language. Most of the students in rural areas come from low income family so that they cannot get enough educational resources compared to students at urban areas. Students who have access to more facilities or resources are getting advantage compared to those from poor families.

\subsection{Logistic support}

Rural areas educational institutions lack enough logistic support compared to urban area educational institutions. Lack of facilities and resources contribute to the poor performances in English language of the students in rural area.

\subsection{Less qualified teachers}

We do not have enough qualified teachers in rural areas. Lack of qualified and trained English teachers in rural areas put poor impact on students English language competence than the urban areas students.

\subsection{Adequate books}

Apart from the good teachers, there are also not adequate books in the educational institutions of rural areas. If we do not bring good and updated English books for students, we cannot guarantee that they would learn the best.

\section{Principles of English Language teaching}

There are certain principles of English language teaching, which are as follows:

3.1 Know your learners- their language background, their language proficiency, their experiential background.

3.2 Identify the learning outcomes including the language demands of the teaching and learning.

3.2 Maintain the same learning outcome for all the learners.

3.3 Begin with context embedded tasks which make the abstract concrete.

3.4 Provide multiple opportunities for authentic language use with a focus on students using academic language.

3.5 Ensure a balance between receptive and productive language.

3.6 Include opportunities for monitoring and self- evaluation.

Phillipson (1992) identifies each of these tenets a fallacy which are as follows:

The monolingual Fallacy.

The native speaker fallacy.

The early start fallacy.

The maximum exposure fallacy.

The subtractive fallacy.

\section{Teaching English language in different level of education in Bangladesh}

In Bangladesh education level is categorized into four stages: Primary, Secondary, Higher Secondary and finally tertiary level. In rural area of Bangladesh we found Primary, Secondary and Higher secondary educational institution and most of the tertiary level educational institution is situated in urban area. So we will look at the scenario of English language in primary, secondary and higher secondary educational institutions.

\subsection{Teaching English language at primary school of Bangladesh}

Jean Piaget, Lev Vygotsky and Jerome Bruner differ in important ways about their explanations of how children develop and learn, but they all agree that cognitive development of the child is linked to construction of knowledge in the brain within a social context (Banu, 2009). They also agree that language development linking sounds, words and meaning as a means of communication is a critical element of cognitive development.

The objectives of English curriculum in Primary school are to:

a. Understand simple command/instructions/requests in English and carry them out.

b. Speak and understand simple English according to their age level. 
c. Read and comprehend text books according to their age group and level.

d. Write alphabets, words, numbers, simple sentences, passages, paragraphs, informal letters and numbers according to their age group and level.

\subsection{English language teaching at the secondary and higher secondary educational institutions}

It is generally agreed that the ability of our learners in English classes, especially at the secondary level is not satisfactory, due to some underlying factors. The syllabus and curriculum are examination oriented and prevent students from acquiring language competency. In rural area English language achievement is very poor regarding the urban area. There are many reasons behind this poor performance. Lack of trained teachers, ineffective course, lack of good deal of content, weak base, large student size and lack of student's active participation are some of the main reasons why the students are lacking behind in English language in secondary and higher secondary in rural areas compared to urban areas.

\section{Literature Review}

The teaching and learning process involves two active participants in the classroom - the teacher and the learner and that language learning do not fall entirely on the teacher. The students must also assume more responsibility for the learning process (Quest, 2000). It is through interactions with each other that teachers and students work together to create intellectual and practical activities that shape both the form and content of the target subject. Furthermore, the English teacher is a figure in the language course. Literature indicates clearly that it is the teacher who sets the tone for learning activities. (Allen and Valette, 1997, Quest, 2000).

Teaching materials are very important in the whole process of teaching and learning to any subject. They make learning more pleasant to the students because they offer a reality of experiences, which stimulates self activity and imagination on the part of the students. Attitudes refer to the sets of beliefs that the learner holds towards members of the target group and also towards his own culture (Brown, 2000). Language attitude is an important concept because it plays a key role in language learning. In education, attitudes are considered both as input and output. Motivation is the most used concept for explaining failure or success of a learner. Also motivation has been regarded as one of the main factors that influence the speed and amount of success of foreign language learners. (Gardener, 2006). It has been seen that passive learning, lack of adequate materials for teaching, motivation of the students and attitudes towards learning keeping the rural area students inefficient in English language compared to urban students.

\section{Problem statement}

Bangladesh has a single unified educational system. However, it has diversity in the local areas in terms of religion, culture, socio-economic conditions etc. As Bangla is spoken by $99 \%$ of the people, the practical use of English, especially in the rural areas, has become extremely limited. Bangladesh has had a long period of academic attachment to English to the acquisition of English as a second language. Against such a background, however, it is generally agreed that the standard of competency of our learners in English is not satisfactory in comparison to the time they expend in learning the language. In rural area of Bangladesh it has been seen that most of the students in this areas could not pass their public exam because of the failure in English subject.

\subsection{Overall objectives of the study}

a. To identify the differences between rural and urban area teaching facilities and system.

b. To find out the reasons behind the incompetency of the students in English subjects regarding the rural area.

c. To find out the teachers and students demand to the government for improving English achievement at the rural areas educational institutions.

\subsection{Importance of the study}

The knowledge of English is more critical as well as important in the context of the global marketplace, the knowledge of society and in the age of digital information technology, Dr. Mohammad Farashuddin (2011), former Governer of Bangladesh Bank, said ' Proficiency in English is a must for the nation to abolish poverty, hunger, disease, illiteracy and indignity. This research is aimed at making contributions towards the quality improvements of English education in rural of Bangladesh. By clarifying the factors that influence students' English achievement, this study attempts to suggests a way of how to improve achievement and effective English policy input in rural area of Bangladesh.

\subsection{Research Questions}

a. What are the factors affecting students' English achievement at the rural area educational institutions students in Bangladesh?

b. What is the actual situation of students' achievement in both rural and urban settings?

c. Which policy inputs are useful in improving students 'English achievement'? 


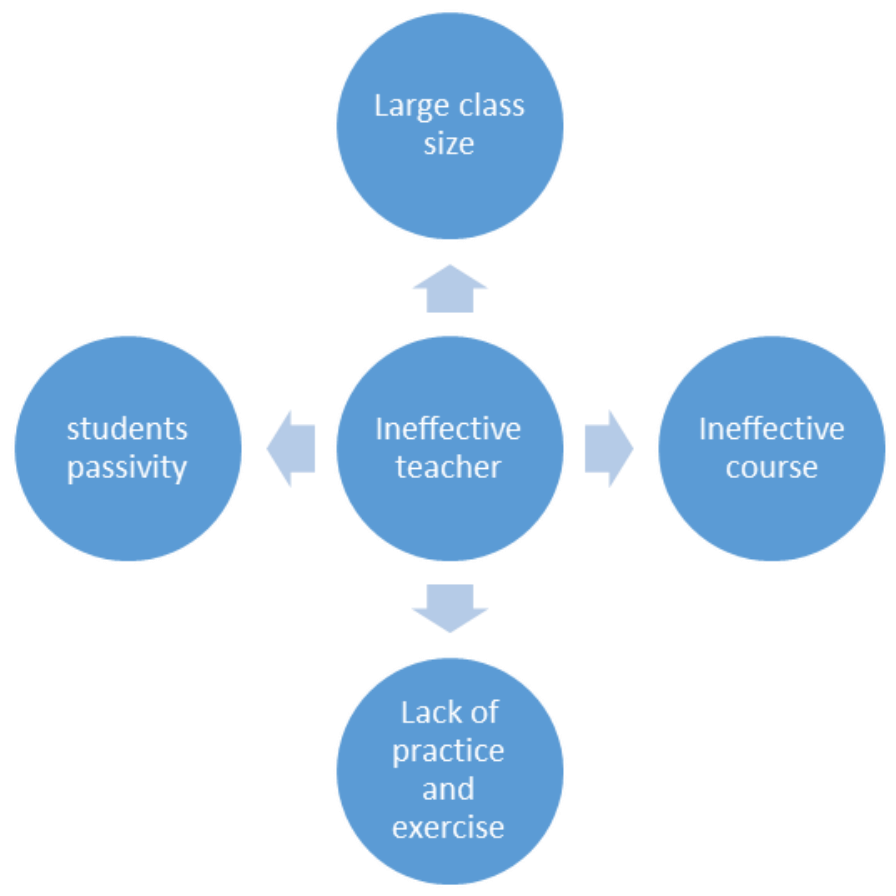

\subsection{Research Method}

To get broad information from rural area students' English achievement, the study primarily relied on first hand evidence, 300 secondary level students, 30 English subject teachers, 50 guardians as well as other documentary evidence. To get to know the actual picture of rural area of English achievement at the secondary level, 6 Secondary level schools (three governments and three non-governments) from Shariatpur areas were selected. All over Bangladesh schools follow unique educational system, identical curriculums and similar textbooks and so on. Moreover, students are sitting the same public examination nationwide. Furthermore, academic instructional time and academic year area alike across the territorial control of the country. Thus, the study arrived out in this region can be generalized to all other regions to a certain extent. The number of students was a total of 300 students. The study was conducted by observation meticulously in the classrooms and distributed questionnaires to the stakeholders', students and English teachers. Most of the oral evidence was noted immediately on the spot.

\subsection{Limitations of the study}

The research was made in Shariatpur region of Bangladesh, interviewed the stakeholders, handed questionnaires and observed the classrooms, related to the research. Most of the work consisted of making note down immediately but did not focus on religious as well as political affairs this area. Moreover, as the study was conducted within some chosen schools, the results of the research cannot describe the entire picture of the rural area English education of Bangladesh.

\subsection{Research Design}

In this study, the qualitative research design is used to describe the stakeholders in their natural settings.

\subsection{Study site}

The study took place in Bangladesh in a rural area, Shariatpur, which stands behind the river Padma, so the communication system in this region is not so good. So the students of this region face communication difficulties to go to their educational institution. Bangladesh is highly diversified in terms of socio-economic aspects. Urban area usually enjoys the comparative advantages in terms of education communication, health care etc compared to rural communities. Shariatpur was selected as a representative of a distinctive rural area of Bangladesh and the standard urban facilities are hardly found in this area. 


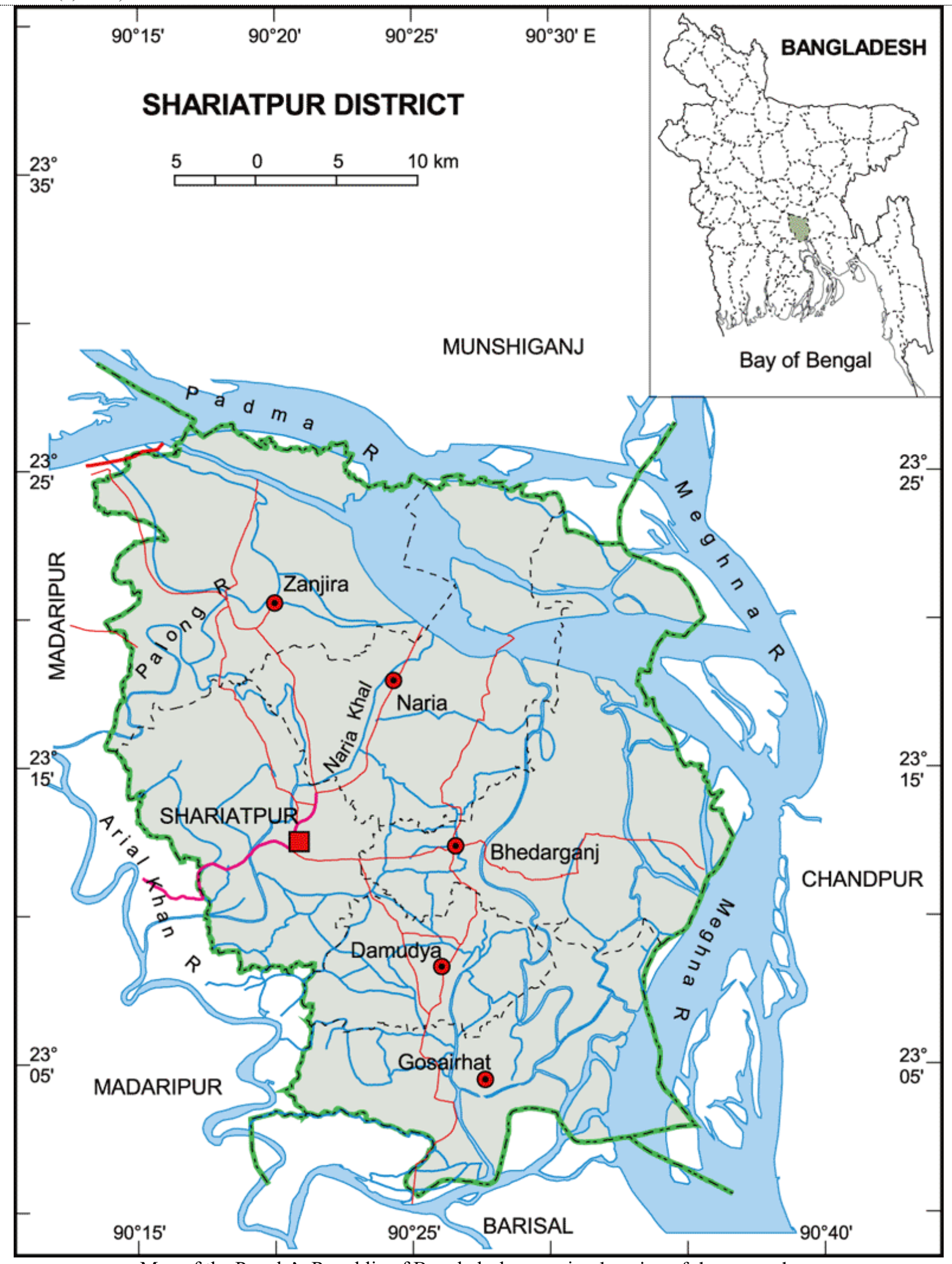

Map of the People's Republic of Bangladesh screening location of the research area

Research area

Shariatpur District

\subsection{Data Analysis}

The data was analyzed by using the percentage method. The study was conducted in October 2015.

\section{Results and Discussions}

As the questionnaires were provided to the subject, they have given different opinions for the low level achievement of English language in rural area.

The factors can be categorized as five main sections: 


\subsection{Lack of practice}

From all respondents $64 \%$ consent that rural area students do not practice English regularly because they believe that English is hard and 36\% do not get interest in learning English.

Figure 1. Lack of Practice
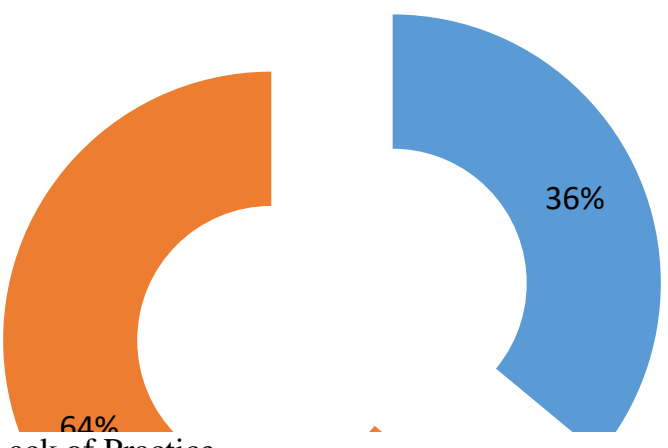

\subsection{Lack of English teacher}

From all respondents $75 \%$ believe that well-trained qualified English teacher do not come to rural area because rural area do not have the facilities like the urban area. 20\% believe that qualified English teacher do not come to rural area because of poor salary. $5 \%$ believe that teachers are not interest to teach in rural area educational institutions because they think it may have an effect in their personality.

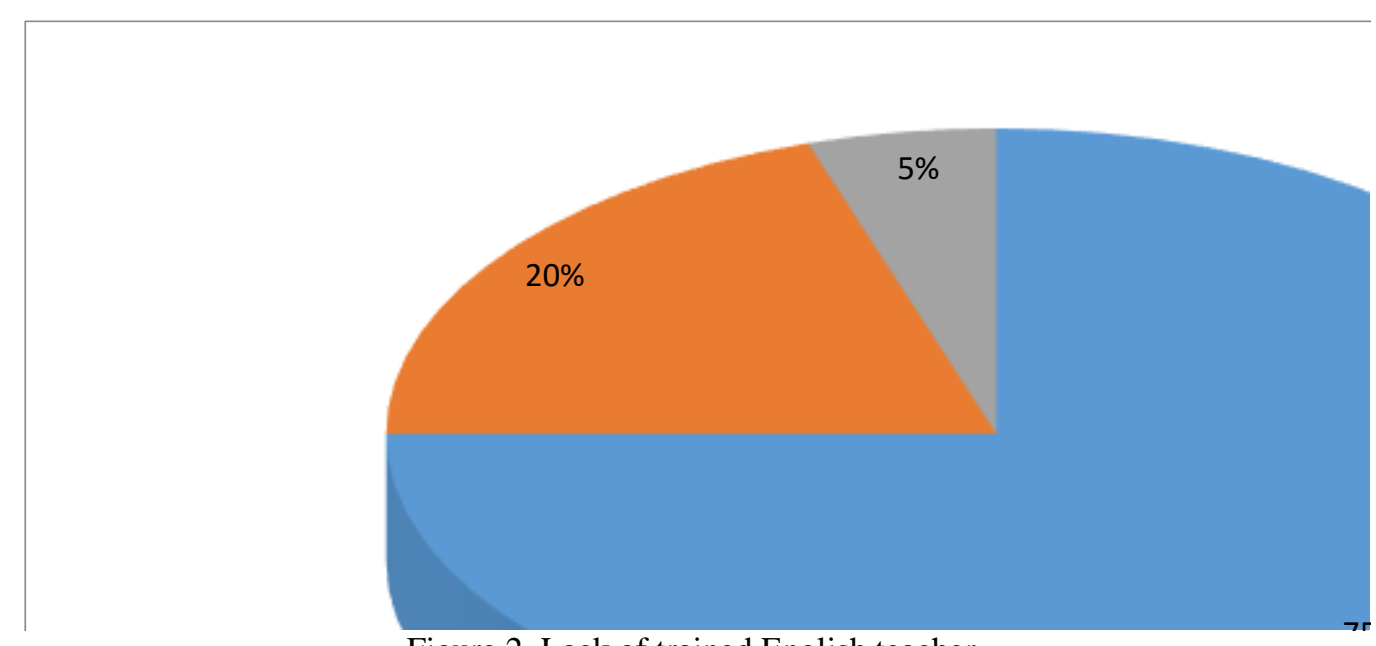

Figure 2. Lack of trained English teacher

\subsection{Proper Teaching method}

From all the respondents, 54\% think that rural teacher do not imply the right way of teaching method so the students are not interested to hear the teacher lesson. $46 \%$ think that teachers do not have any lesson plan before a class and for this reason they could not imply the proper teaching method in classroom.

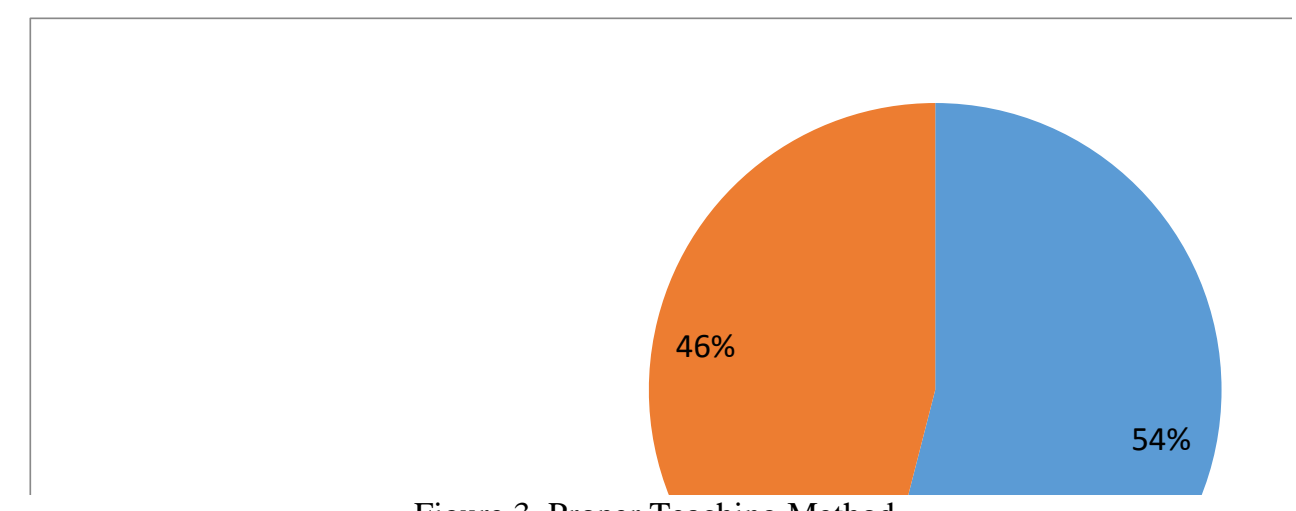

Figure 3. Proper Teaching Method 
$84 \%$ respondents gave their opinion that environment plays a key role in learning a second language which is mostly absent in rural areas schools and colleges and its classroom.16\% think that rural atmosphere needs to be improved for learning second language.

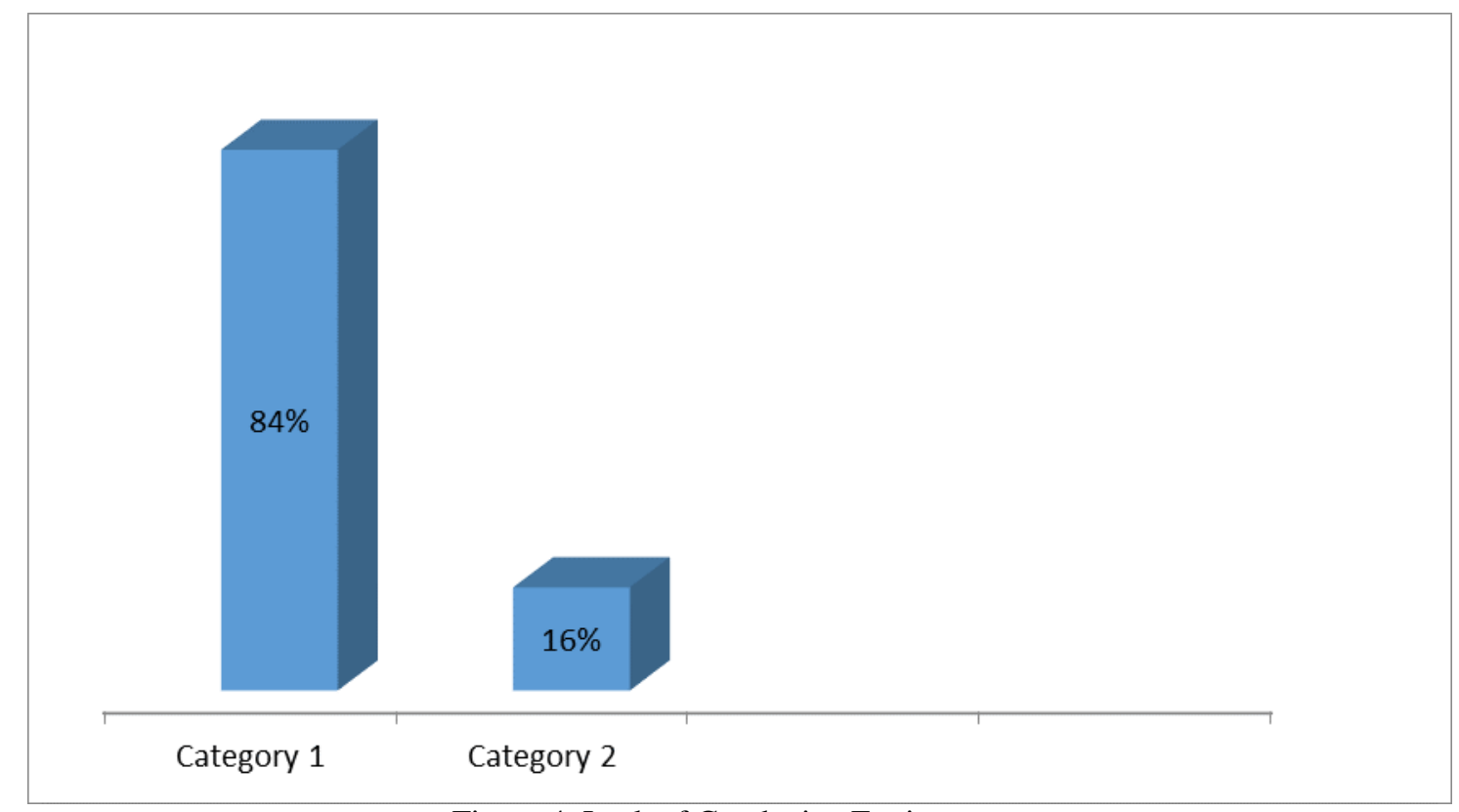

Figure 4. Lack of Conducive Environment

\subsection{Lack of library facilities}

Among all respondents, $30 \%$ consent that there is not enough library facilities, $40 \%$ consent there is not enough updated books and $30 \%$ consent that unavailability of the quality books is another reason for poor English achievement in rural English.

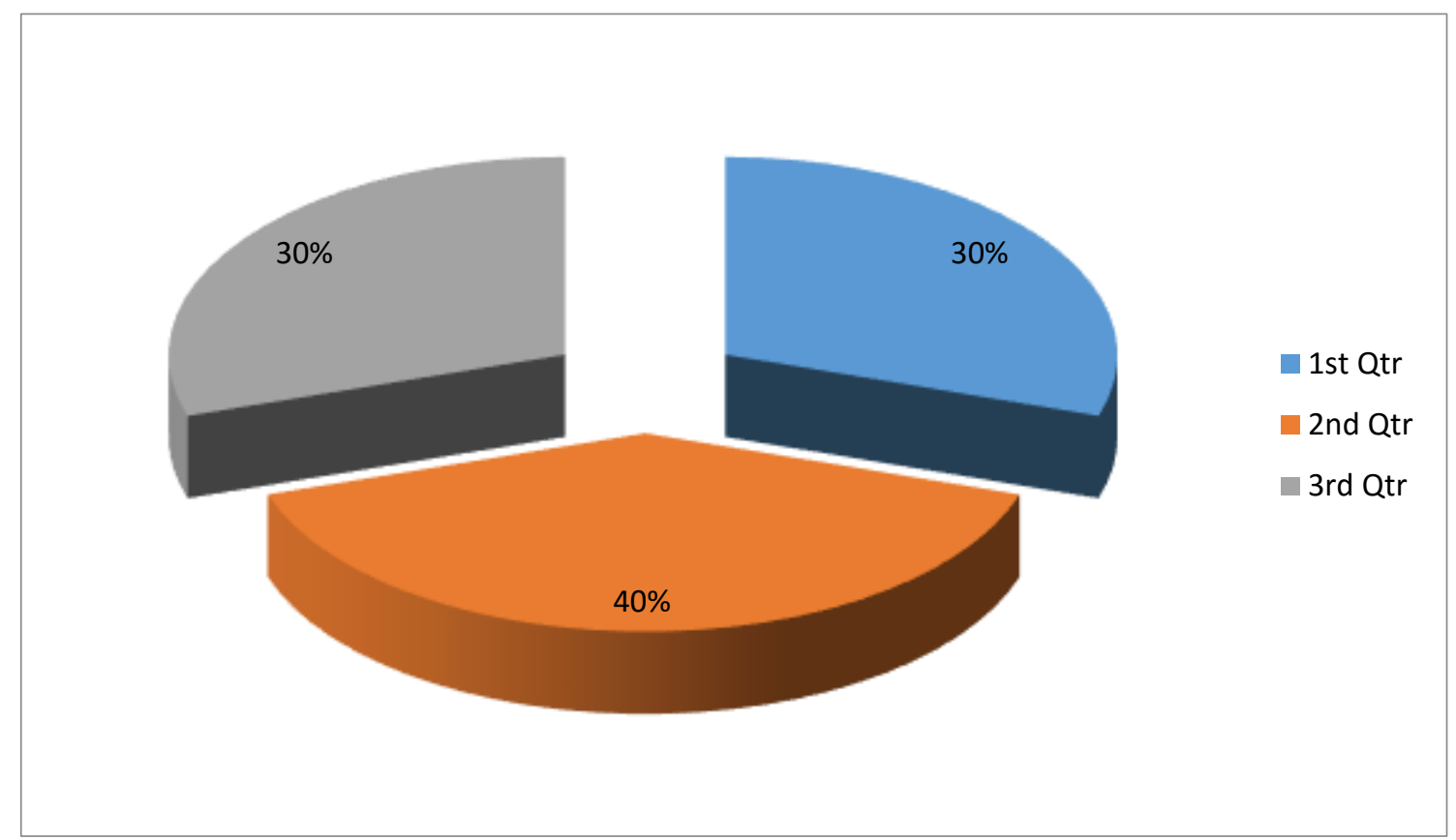

Figure 5. Lack of Library Facilities

Apart from this opinion the students also give opinion about the different activities that is done in the rural area educational institutions regarding to improve the students receptive and productive skills.

7.6 Speaking exercise in the classroom

From all the students that has given their opinions, 5\% consent that in rural areas English teachers always make speaking exercise in the class, while $20 \%$ consent that English teachers sometimes make speaking exercise in the classrooms and $75 \%$ admit that English teacher rarely make speaking exercise in the class. 


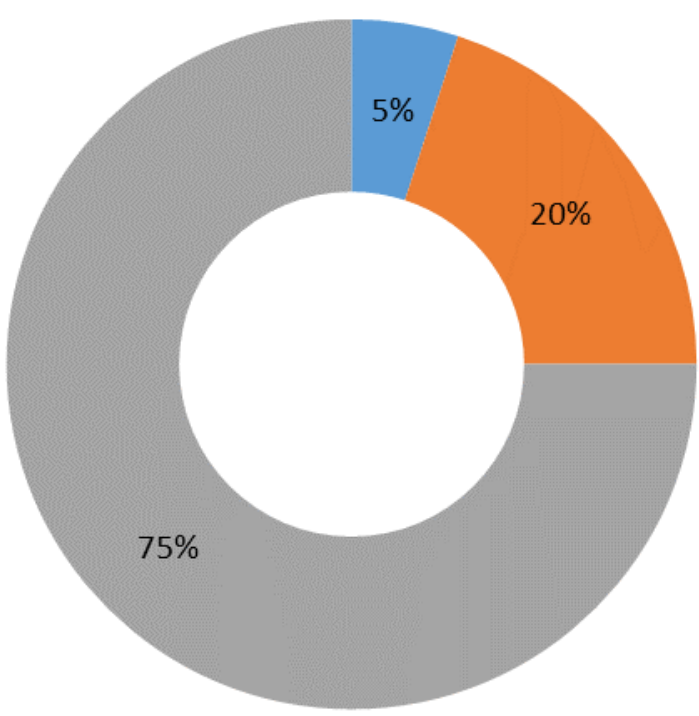

1st Qtr

2nd Qtr

ard Qtr

Figure 6. Speaking Exercise in the Classroom

\subsection{Writing exercise in the classroom}

Students of rural area of this region claim that teacher don't make regular writing exercise. From all the students , 5\% consent that English teacher always make writing exercise regularly while $45 \%$ sometimes make writing exercise in the class whether $50 \%$ think that English teacher rarely make writing exercise in the class.

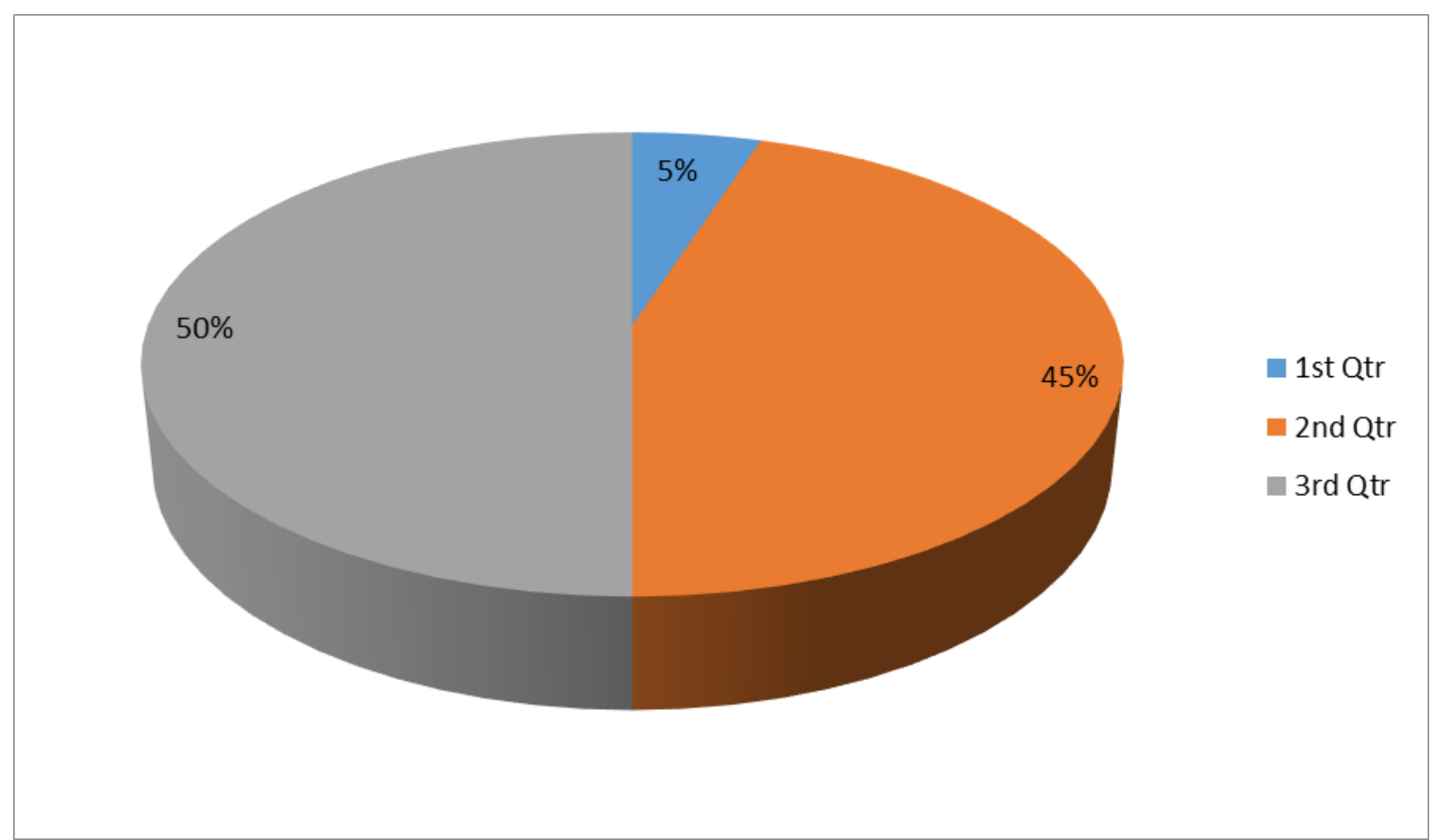

Figure 7. Writing exercise in the classroom

7.8 Reading Exercise in the classroom

From all the students $20 \%$ consent that English teacher always make reading exercise in the class whether $70 \%$ consent that sometimes English teacher make reading exercise and 10\% think that English teacher rarely make reading exercise in the class. 


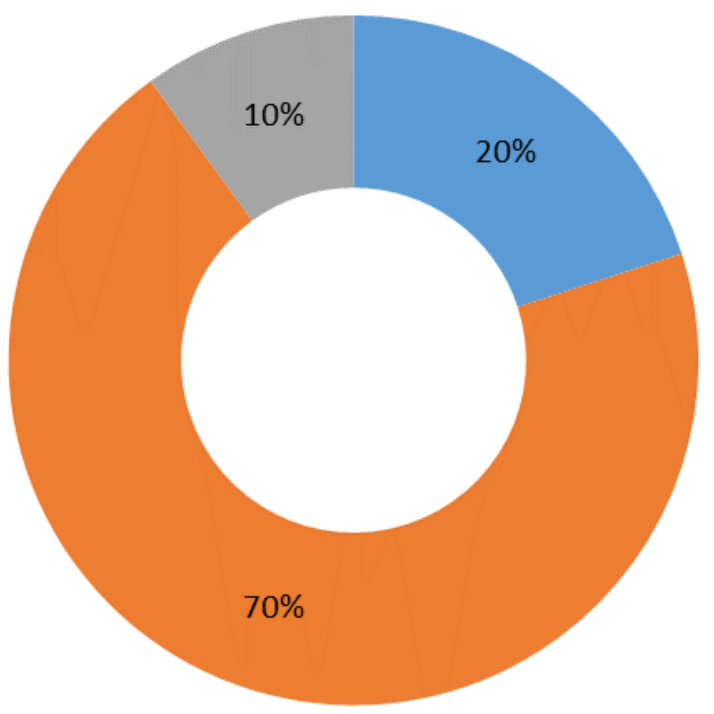

1st Qtr

2nd Qtr

3rd Qtr

Figure 8. Reading exercise in the classroom

\subsection{Listening exercise in the classroom}

All students claim that no listening practice is done in the classroom because there is no listening material for the teacher to use it.

\section{Classroom observation checklist}

From the classroom observation it can be analyzed that rural area teachers found difficulty in classroom management, time management, technique of evaluation and ways of giving feedback.

\subsection{Classroom Management}

From the observation of classroom in the rural area of educational institutions, it was found that $4 \%$ teachers are excellent in terms of classroom management, $10 \%$ teachers are good in terms of classroom management, $35 \%$ are in average performer and $35 \%$ are in below average conditions where $16 \%$ teachers are totally unable in terms of classroom management.

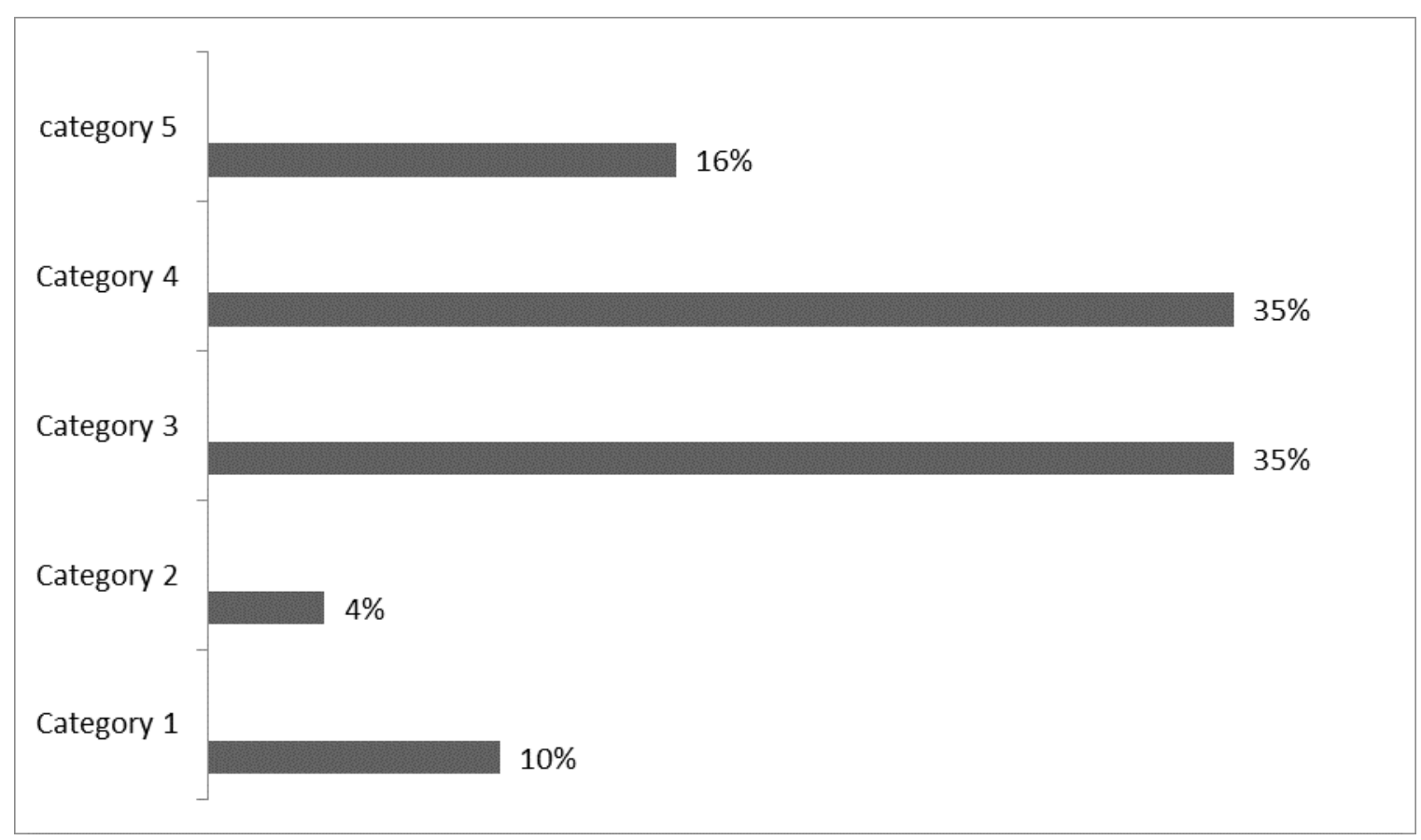

\subsection{Time Management}

Figure 9. Classroom Management

From the observation, it was found that $5 \%$ teachers are excellent in time management while $25 \%$ teachers are good in time management, $30 \%$ are in average in time management, $25 \%$ teachers are below average in time management and 155 teachers do not maintain any time schedule which effect students learning. 


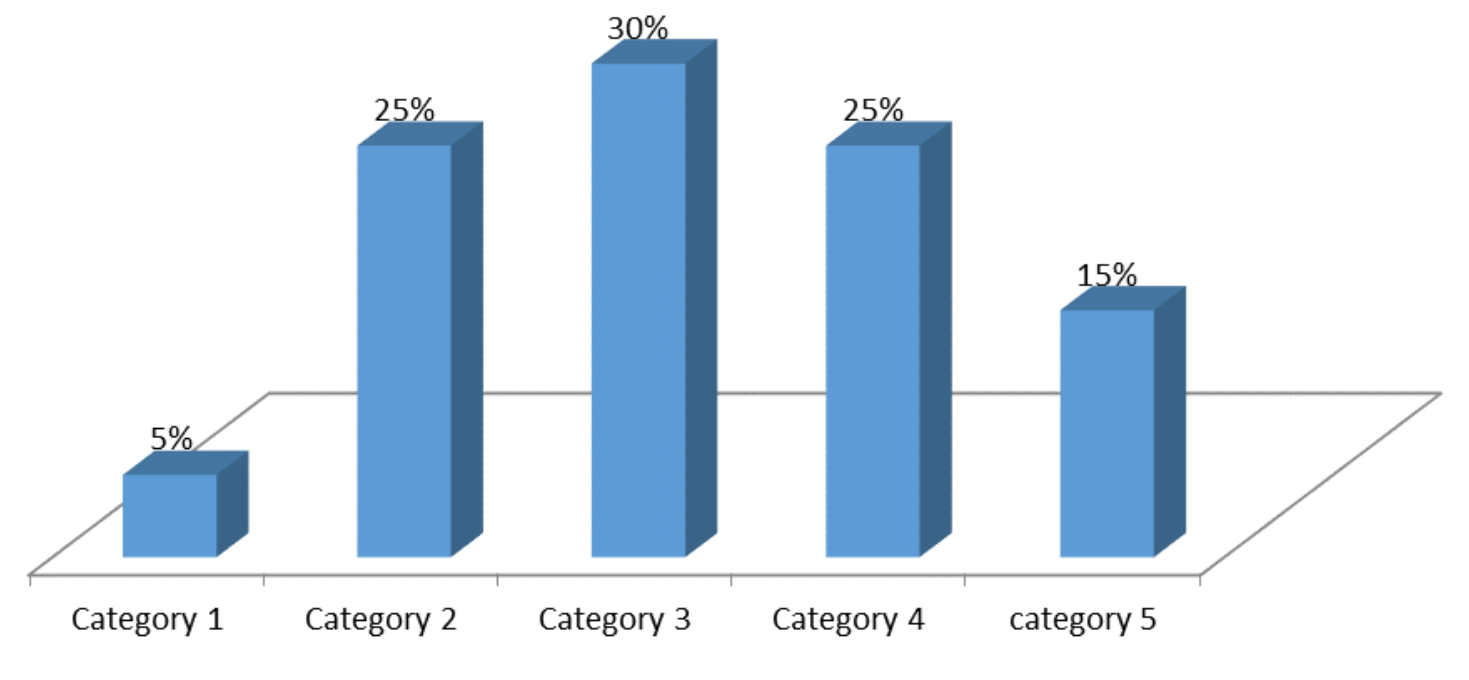

Figure 10. Time Management

\subsection{Technique of evaluation}

From the observation of sample classroom, it was found that $10 \%$ teachers followed excellent evaluation technique, $10 \%$ teachers are good in using technique of evaluation, $15 \%$ are in average, $35 \%$ are in below average and $30 \%$ are totally unable to use technique of evaluation as a result they can't evaluate students learning.

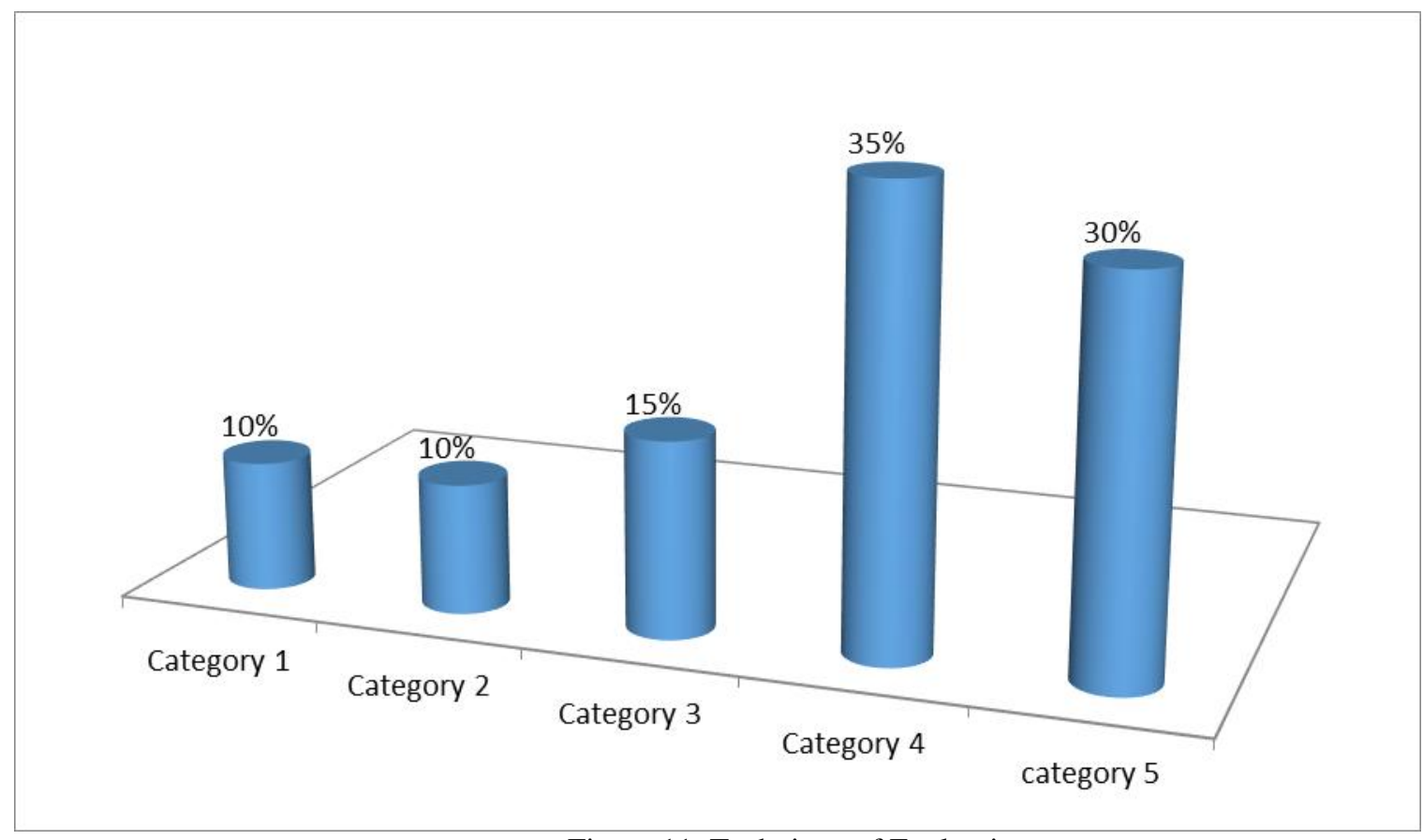

\subsection{Giving Feedback}

Figure 11. Technique of Evaluation

By observing the classrooms, it was found that only $4 \%$ teacher's have excellent feedback ability while $15 \%$ have good feedback ability and 19\% average skill to give appropriate feedback , 32\% are below average and 30\% teacher's have no skills or do not give feedback to the students learning. 


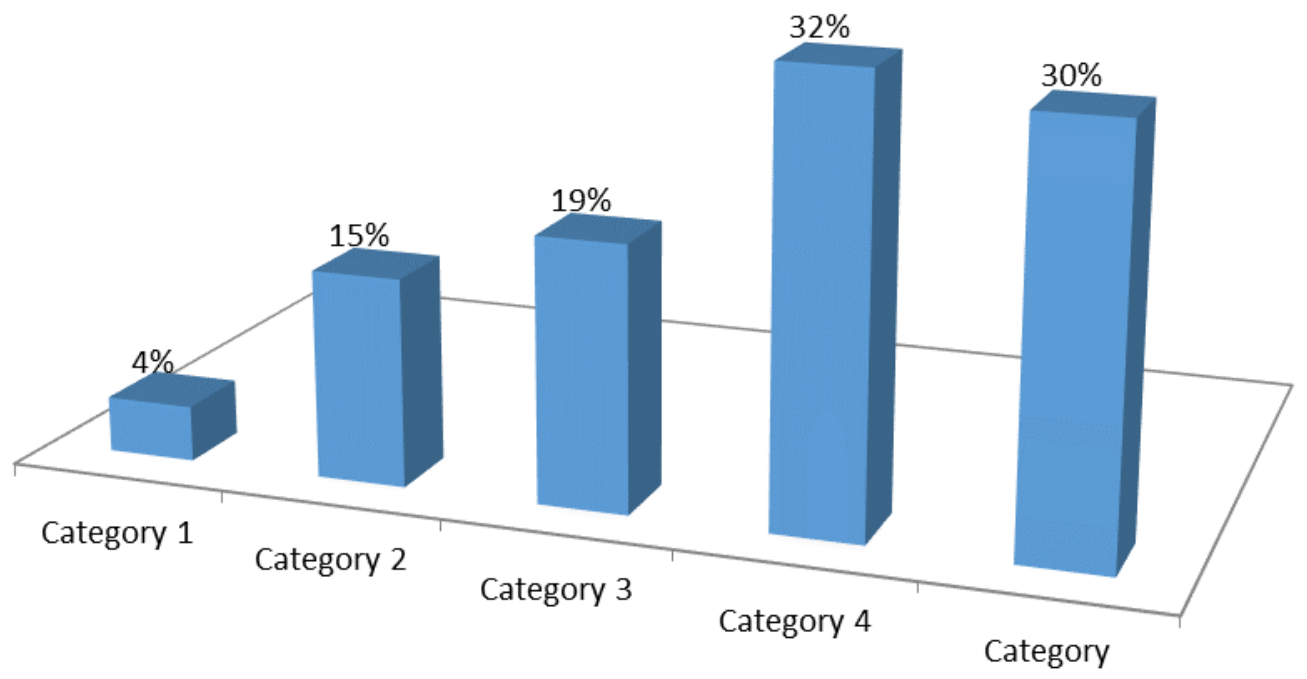

Figure 12. Giving Feedback

9.5 Use of Modern Technology

From the observation, it was found that $6 \%$ are excellent in using modern technology in the classroom, $6 \%$ are good in using modern technology, $6 \%$ are average and $82 \%$ teachers have no skills in using modern technology.

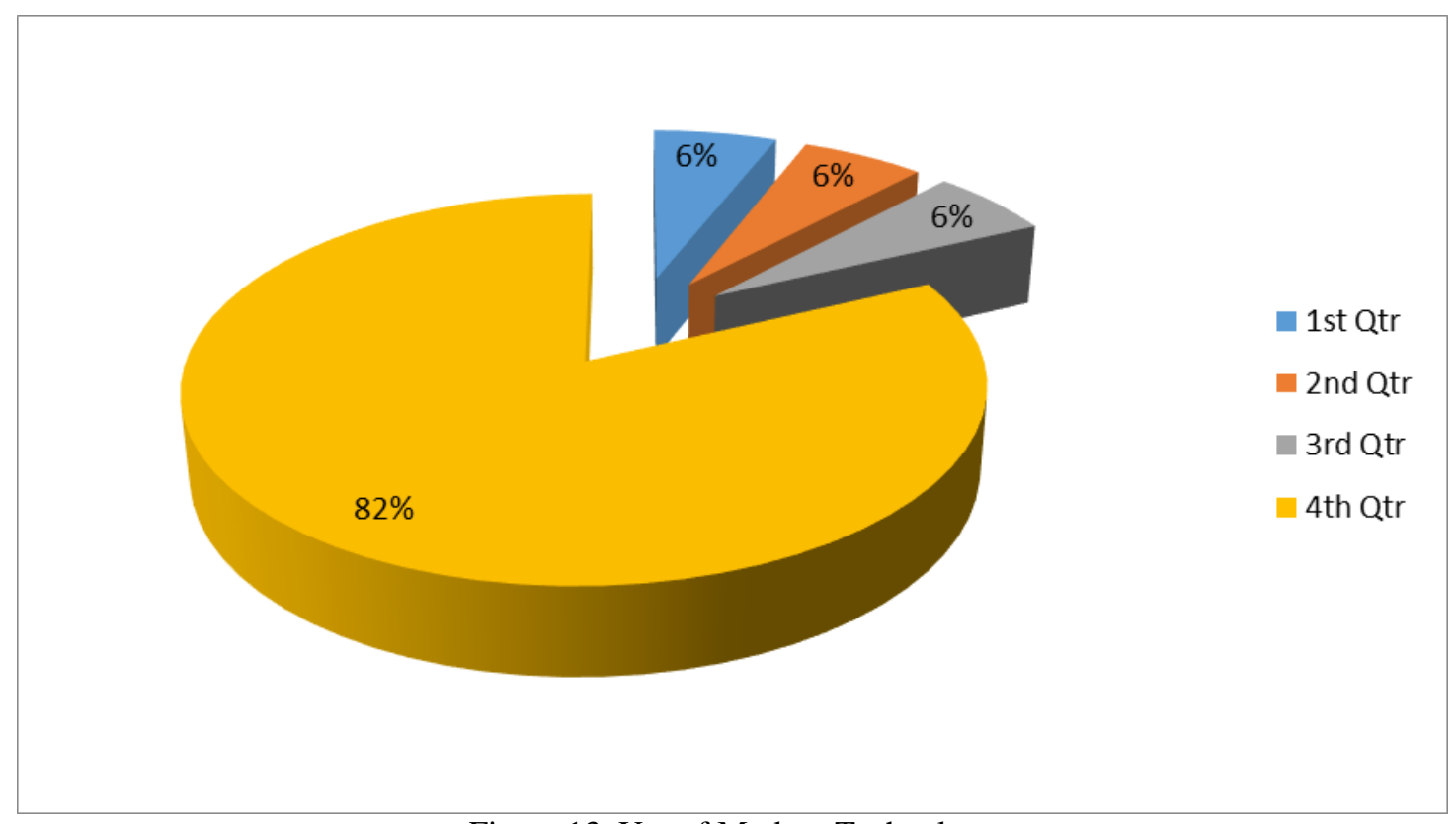

\section{Recommendation}

Figure 13. Use of Modern Technology

In spite of the rural area educational institutions and the students of these institutions are lacking behind in English language proficiency certain steps can be taken to improve the scenario of English language proficiency of rural area students and to bring a revolutionary change in the rural area educational institutions atmosphere. These are:

a. Organize English subject related training for the teacher.

b. Proper management of classroom from beginning to end.

c. Try to focus on the four skills of English language that is reading, writing, listening and speaking.

d. Encourage the students to do exercise based on four skills.

e. Provide enough teaching aid for the teacher.

f. Implementation of proper teacher-learning techniques mentioned in the curriculum.

g. Encourage the students to become active in the classroom.

h. Learning objectives should be set before any course is introduced.

i. Make sure that the teacher made proper lesson plan for each class.

j. Recruitment of more English teacher is needed to decline teacher-student ratio. 
k. A stimulating atmosphere for language teaching can be created by displaying posters, charts, maps, advertisements, time-table and signs together with works produced by the students themselves in the classroom.

\section{Conclusion}

Since English is the foreign language to the people of Bangladesh, students of our country find it complex task in their education. It is a matter of great sorrow that effective implementation of English curriculum is still far away. Especially in rural areas of Bangladesh, English is yet the matter of fear for students. Urban students are comparatively adroit in English language because school teachers are skilled in English language teaching and they get support from parents and house tutors. But in rural areas, most of the parents are not educated and unable to spend money for private tutor. If teachers become qualified and conscious to teach students, it will be helpful for rural students to learn English effectively. To emancipate the fear of English language learning among the rural students and to achieve the curriculum goals and objectives, government and non-government organization, whose are trying to improve English language skills of area students, should take some short and long terms plan by considering existent condition of English language learning and the prevailing problems which are hindrances for implementing English curriculum.

\section{References}

Allen, E, and Valette, R. (1997). Classroom Technique: Foreign Languages and English as a second Languages and English as a second Language. San Diego, Harecourt Brace Jovanovich.

Banu, L.F.A (2009). Problems and Misconceptions Facing the Primary Language Education in Bangladesh: An Analysis of Curricular and Pedagogic practices, BRAC University Journal, 6(1-10),6. Institute of Educational Development, BRAC University.

Brown, H.D (2000). Principle of Language Learning and teaching, New Jersey, NY : Mcgraw-Hill.

Di Pietro, R (1994). Helping people do things with English. In Kral, T. Teacher development: Making the right moves, Washington, DC: English language programmes Division.

Esterman, A. and Hedlund, R. (1995). Smith Beaulieu and seraphine. X.

Farashuddin (2011) $5^{\text {th }}$. Bangladesh English Language Teachers Association (BELTA). International conference at city's BIAM Foundation, Dhaka.

Gardner, R.C. (1985a). Social Psychology and Second Language learning: The Role of attitude and motivation. London: Edward Arnold Publishers.

Garder, R.C (2006). The social educational model of second language acquisition: A research paradigm. EUROSLA Yearbook, 6(1) 237-260.

Hasan, K. (2005). A Linguistic study of English language curriculum at the secondary level in Bangladesh. A communicative Approach to curriculum Development. Language in India, 48, 1-240.

Krashen, S. (2002- First internet edition, December-2002). Second Language Acquisition and Second Language Learning. University of Southern California.

National curriculum and Textbook Board (2006). Compulsory curriculum (Primary education). Retrieved January 25, (2012).

Philipson, R. (1992). Linguistic Imperialism. Oxford: Oxford University Press.

Quist, D. (2000). Primary teaching methods. London: Macmillan. 